\title{
Experimental Study and Performance Analysis of Ceramic Packing Cooling Tower Using Taguchi Method
}

\author{
Ramkumar Ramakrishnan*, Ragupathy Arumugam \\ Department of Mechanical Engineering, Annamalai University, Annamalai Nagar-608002, Tamilnadu, India
}

\begin{abstract}
Deterioration of the packing material is a major problem in cooling tower. In this experimental study, ceramic tile is used as packing material. The experimental study was conducted in a forced draft cooling tower. Cooling tower operating parameters were optimized using Taguchi approach. The application of Taguchi method is assessing maximum cooling tower effectiveness for the Forced draft counter flow cooling tower using ceramic packing. An experimental study has been carried out for Taguchi's L9 orthogonal array. According to Orthogonal array the trail was performed under different inlet conditions of flow rate of water, air and Inlet water temperature. Signal-tonoise ratio $(\mathrm{S} / \mathrm{N})$ and regression were carried out in order to determine the effects of process parameters on cooling tower effectiveness. Finally confirmation tests verified this reliability of Taguchi method for optimization of forced draft counter flow cooling tower performance with sufficient accuracy. Confirmation experiment was done using optimum combination showed that cooling tower effectiveness was found by experiment is closer to the predicated value.
\end{abstract}

Keywords: optimization, Cooling tower, ceramic packing, performance, Taguchi Method, Regression

\section{Introduction}

The cooling tower is a steady flow device that uses a combination of mass and energy transfer to cool water by exposing it as an extended surface to the atmosphere. The water surface is extended by filling, which presents a film surface or creates droplets. The air flow may be cross flow or counter flow and caused by mechanical means, convection currents or by natural wind. In mechanical draft towers, air is moved by one or more mechanically driven fans to provide a constant air flow. The function of the fill is to increase the available surface in the tower, either by spreading the liquid over a greater surface or by retarding the rate of fall of the droplet surface through the apparatus. The fill should be strong, light and deterioration resistant. The operating theory of cooling tower was first suggested by Walker [1]. Simpson and Sherwood studied the performances of forced draft cooling towers with a $1.05 \mathrm{~m}$ packing height consisted of wood slats [2]. Kelly and Swenson studied the heat transfer and pressure drop characteristics of splash grid type cooling tower packing [3]. Barile et al studied the performances of a turbulent bed * Corresponding author. Tel: +9104144-237092

E-mail: rrramkumar_hai@yahoo.com

(C) 2014 International Association for Sharing Knowledge and Sustainability

DOI: $10.5383 /$ ijtee.08.01.006 cooling tower characteristic with the water/air mass flow ratio [4]. The packing is the most crucial part of the cooling tower. The purpose of the packing material is to provide a large surface area for contact between air and water by distributing the water flow uniformly to enhance evaporation and heat transfer. As the water flows down the packing, it contacts air that is forced across the packing by a fan. A small percentage of the water evaporates by cooling the water. The relatively small portion of the water droplets in the air stream is called as "drift". The warm, moist air then passes through the drift eliminator and exits at the top of the tower, by carrying out some of the drifts out of the tower. Kloppers and Kroger [5] studied the loss coefficient for wet cooling tower fills. They tested trickle, splash and film type fills in a counter flow wet cooling tower with a cross sectional test area of $1.5 \mathrm{~m}$ X $1.5 \mathrm{~m}$. Abdulrahman et.al., [6] experimental investigation on the performance of a direct evaporative cooler in hot and humid regions. The direct evaporative cooler consists of a cellulose pad with a surface area per unit volume ratio of 100 $\mathrm{m}^{2} / \mathrm{m}^{3}$. The performance of the evaporative cooler is evaluated using the output temperature, saturation efficiency, and cooling capacity. 
A new form of empirical equation that correlates fill loss coefficient as a function of the air and water mass flow rates. There exist several other mathematical models which can correlate heat and mass transfer processes occurring in wet cooling towers, such as the models proposed and discussed by Khan et al. [6] and Kloppers and Kroger [7]. Vertical grid apparatus(VGA) type packing was first proposed for the mass transfer processes between gas and liquid [8] and has been used in cooling water systems using direct contact between water and air. Therefore, this study presents an experimental investigation of the thermal performances of cooling towers filled with the "V.G.A." type packing. This packing consists of vertical grids disposed between walls in the form of zigzag. The principle of its performance is as follows: the gas (air) enters by the bottom of the tower and arrives by the top of that while crossing several times the vertical grids, whereas the liquid(water) is introduced at the top of the tower and flows along the vertical grids. Lemouari [9] and Lemouari and Boumaza $[10,11]$ used this packing in an evaporative cooling system to study its thermal and hydraulic performances. Experimental study was conducted in forced draft cooling tower using wire mesh and ceramic packing by Ramkumar and Ragupahty $[12,13]$. From his study cooling tower effectiveness, cold water temperature and mass transfer coefficient were analysed. Esam Elsarrag [14] studied experimentally the long life burned clay is used as the filling material and the heat and mass transfer coefficients was conducted. Amin Mezoued and Kaabi [15] demonstrate the effect of the packing material on the performance of the double pass (PVT) solar air heater in terms of energy and exergy. The results show that the presence of packing material in the lower channel of double pass photovoltaic-thermal (PVT) air collector increases the convective heat transfer. This improves the energy and exergy performance.

Naphon [16] performed a study on the heat transfer characteristics of an evaporative cooling tower. The tower was $0.15 \mathrm{~m} \mathrm{X} 0.15 \mathrm{~m}$ internal cross section, and $0.48 \mathrm{~m}$ in high packed with eight layers of the laminated plastic plates. He presented theoretical and experimental results of the heat transfer characteristics of the cooling tower making a comparison between them. However, the author did not suggest any empirical correlation for the heat transfer characteristics of the tower. Elsarrag [17] presented an experimental study and predictions of an induced draft ceramic tile packing cooling tower. He used a tower of $0.64 \mathrm{~m}^{2}$ cross section area and $2 \mathrm{~m}$ height with a filling portion of $0.8 \mathrm{~m}$. Burned clay bricks were used as the packing material in his work. The author pointed out that the factors affecting the heat and mass transfer coefficients are the water to air flow rate ratio, the inlet water temperature and the inlet air enthalpy. Gharagheizi et al. [18] presented an experimental and comparative study on the performance of mechanical cooling tower with two types of film packing. They used vertical corrugated packing (VCP) and horizontal corrugated packing (HCP) having $0.64 \mathrm{~m}$ in high and $0.25 \mathrm{~m}^{2}$ cross section area. These authors reported that the performance of the cooling tower is affected by the water/air mass flow ratio, the type and the arrangement of the packing. Besides the early experimental investigations, there exist several other mathematical models that correlate heat and mass transport phenomena and performance characteristics relative to direct-contact counter flow wet cooling towers, such as the models described in Benton and Waldrop [19] , Kloppers [20], Fisenko et al. [21], Fisenko and Petruchik [22], Khan et al. [23], Qureshi and Zubair [24] and Heidarinejad et al. [25] .
This study presents an experimental investigation of effectiveness of the cooling tower with optimization techniques using Taguchi method. There is no reports in literature on the optimization techniques using Taguchi method on counter flow cooling tower using ceramic packing materials. From the experimental study cooling tower effectiveness was identified with best optimum cooling tower operating parameters using different shape of ceramic packing materials.

\section{Experimental Setup}

The tested cooling tower is a forced draft counter flow type. A schematic diagram of the experimental apparatus is shown in Figure 1(a) \&1(b). The main part of the installation is the cooling tower, $1.5 \mathrm{~m}$ in height and $0.3 \mathrm{mx} 0.3 \mathrm{~m}$ in cross section. Water is transported by pump through flow regulated valve. The water flow rate is measured by flow meter and distributed through spray nozzles. Water is distributed in the form of falling films over the ceramic packing. The water distribution system consists of 6 numbers of $2 \mathrm{~mm}$ diameter nozzles. By using this

System water is directly distributed over the ceramic packing, and the films of falling water were uniform across the whole surface of packing. The pressure drop at fill zone is measured by U-tube manometer. Chromel-alumel thermocouples were used to measure water inlet and outlet temperature and measure the water temperature in fill zone area. All thermocouples were connected to a 24 point digital temperature recorder. A forced draught fan was used to provide air flow to the tower. The air enters into tower, passes the packing zone and leaves the tower. The parameters and their corresponding range are given in Table 1.

Table 1 Cooling Tower Operating Parameters and Range

\begin{tabular}{ll}
\hline Parameter & Range \\
\hline Water flow $(\mathrm{kg} / \mathrm{hr})$ & $100-200$ \\
Air flow $(\mathrm{kg} / \mathrm{hr})$ & $100-200$ \\
Inlet water temp $\left({ }^{\circ} \mathrm{C}\right)$ & $40-48$ \\
\hline
\end{tabular}

The Cooling tower effectiveness is the ratio of range to the ideal range.

$$
\begin{gathered}
\operatorname{Effectiveness}(\varepsilon)=\frac{\operatorname{Range}(\mathrm{R})}{\operatorname{Range}(\mathrm{R})+\operatorname{Approach}(\mathrm{A})} \\
\varepsilon=\frac{\mathrm{T}_{\mathrm{wi}}-\mathrm{T}_{\mathrm{wo}}}{\mathrm{T}_{\mathrm{wi}}-\mathrm{T}_{\mathrm{wbi}}} \\
\operatorname{Range}(\mathrm{R})=\mathrm{T}_{\mathrm{wi}}-\mathrm{T}_{\mathrm{wo}} \\
\operatorname{Approach}(\mathrm{A})=\mathrm{T}_{\mathrm{wo}}-\mathrm{T}_{\mathrm{wbi}}
\end{gathered}
$$




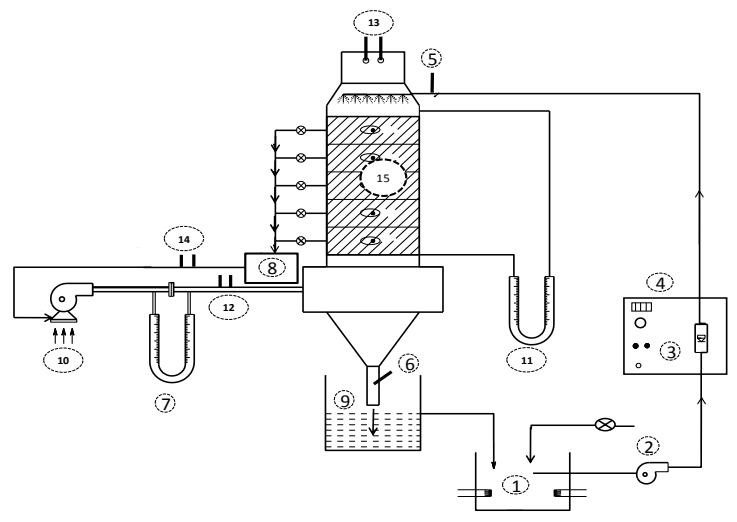

(a)
1. Water Heater,
2. Pump,
3. Flow Meter
4. Temp Display \& control,
5. Hot water Thermometer,
6. Coldwater Thermometer,
7. U-Tube Manometer - air flow, 8. Psychometric Gun,
9. Receiving Tank, 10. Forced Draft Fan,

11. U-Tube Manometer $-\Delta \mathrm{P}$ of pakcing,

12. Air Inlet Temperature. $\left(\mathrm{T}_{\mathrm{DB} 1} \mathrm{~T}_{\mathrm{WB} 1}\right)$,

13. Air outlet temperature $\left(\mathrm{T}_{\mathrm{DB} 2} \mathrm{~T}_{\mathrm{WB} 2}\right)$,

14.Psychometric Gun Temperature

15. Expanded wire mesh fill

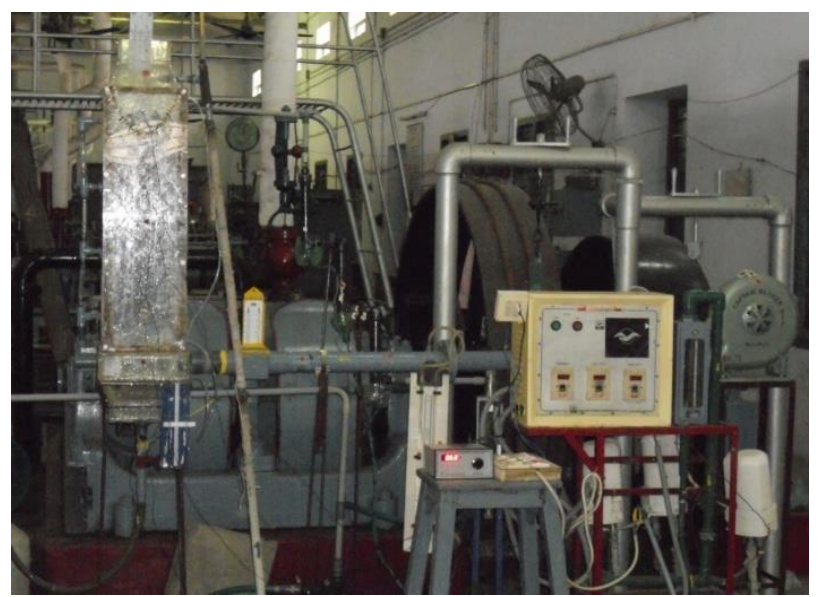

(b)

Fig. 1 (a) Line diagram of Forced Draft cooling tower, (b) Experimental setup of cooling tower

\section{Ceramic Tile Packing}

In the experimental study, ceramic tile packing was used as tower packing material. This type of packing is considered as unique for film packing. The forming of ceramic packing is made in such a way that each little aperture acts as directing vane for air, moving bulk of air alternately from one side to other. Its hardness, strength and composition guard against common cooling tower problems resulting from fire, chemical water treatment and deterioration. The packing materials are curved and triangular shape with length of $0.28 \mathrm{~m}$ and $10 \mathrm{~mm}$ thickness. Shape of the ceramic packing material are $20 \mathrm{~mm} \& 100 \mathrm{~mm}$ curved and Triangular shape. This action results in air travelling a distance of about $1.25 \mathrm{~m}$ through the total depth of packing. Compared with different standard cooling packings, ceramic packing provides the minimum restriction to the passage of air. The photographic pictures of the packings with dimensions are shown in Fig. 2.
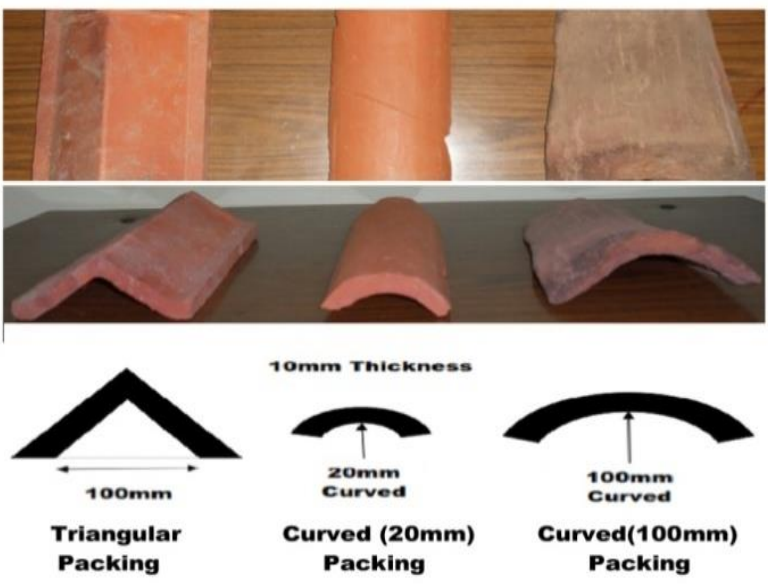

Fig.2 Photographic picture of the ceramic pacing

\section{Material and Method}

\subsection{Design and analysis of experiments}

Design of experiment is a powerful statistical method for determining the unknown properties of the operating parameters in the experiment process and for analyzing and modeling the interaction among the factors [26]. The classical experimental design methods are too complex and not easy to use. Additionally, a large numbers of experiments have to be carried out when the number of operating parameters increases [27]. Therefore, the factors causing variations should be determined and checked under laboratory conditions. These studies are considered under the scope of off-line quality improvement [28].

\subsection{Taguchi's method}

There are various methods used for improving the quality in variety of industries. Taguchi method is one of the best optimization technique to achieve high quality without increasing cost. It is a simple, systematic and powerful method to increase the quality $[29,30]$. The advantage of this method is to reduce both product cost and number of experiments required [31]. Mathematical and statistical techniques are combined in Taguchi method. In this research work, Taguchi's method is used for improving the effectiveness in the cooling tower . Two important tools employed in Taguchi's method are signal to noise ratio ( $\mathrm{S} / \mathrm{N}$ ratio) and orthogonal arrays $(\mathrm{OA})$ [32].

In Taguchi method, first, significant process parameters and their levels are selected. The ranges of these parameters were selected on the basis of preliminary experiments conducted by using one variable at a time approach [33]. In this research work, three control factors and three levels are chosen for analyzing the effectiveness. The most significant process parameters considered as control factors and their levels are shown in Table 2. 
Table 2 Process parameter with their ranges and values at three levels

\begin{tabular}{|l|l|l|l|l|l|l|}
\hline Sl & Parameters & $\begin{array}{l}\text { Process } \\
\text { No }\end{array}$ & Designation & Range & \multicolumn{2}{|l|}{ Level } \\
\cline { 4 - 7 } & Parameters & & Low & Medium & High \\
\hline 1 & A & $\begin{array}{l}\text { Water } \\
\text { Flow } \\
(\mathrm{kg} / \mathrm{hr})\end{array}$ & $\begin{array}{l}100- \\
200\end{array}$ & 100 & 150 & 200 \\
\hline 2 & B & $\begin{array}{l}\text { Air Flow } \\
(\mathrm{kg} / \mathrm{hr})\end{array}$ & $\begin{array}{l}100- \\
200\end{array}$ & 100 & 150 & 200 \\
\hline 3 & $\mathrm{C}$ & $\begin{array}{l}\text { Water } \\
\text { Temp }\left({ }^{\circ} \mathrm{C}\right)\end{array}$ & $40-48$ & 40 & 44 & 48 \\
\hline
\end{tabular}

\section{Selection of Orthogonal Array (OA)}

In Taguchi method, experimental analysis is based on orthogonal array. Orthogonal array is used to minimize the number of experiments, by which quality characteristics are examined [34]. The appropriate OA is selected on the basis of total degrees of freedom required [35]. By using number of factors, number of levels of each factor and number of interactions DOF is determined. In this research work, the interaction effect between the process parameters is not considered. The degree of freedom for three levels is $2(\mathrm{DOF}=$ number of levels - 1). The required total DOF for three factors and three levels is $6(3 \times(3-1)=6)$.In Taguchi method, the total DOF of selected OA must be greater than or equal to the total DOF required for the experiment. Hence L9 OA having eight DOF is selected in this research work. The Table 3 shows L9 OA which has four columns and nine experiment runs.

\subsection{Signal to Noise ratio}

In Taguchi method, signal to noise ratio ( $\mathrm{S} / \mathrm{N}$ ratio) is employed to analysis the quality characteristics of the product or process parameters. It is also called as statistical measure of performance [36]. It is the ratio of the mean (signal) to the standard deviation (Noise). Regardless of the category of the quality characteristic, process parameter settings with the highest $\mathrm{S} / \mathrm{N}$ ratio always yield the optimum quality with minimum variance [37].The following three types of $\mathrm{S} / \mathrm{N}$ ratios are considered to be standard and are widely applied in Taguchi method [38].

\section{(1). Smaller is better}

$\eta=-10 \log 1 / n \sum_{i=1}^{n} y_{i}^{2}$

(2). Nominal is the best

$\eta=-10 \log 1 / n \sum_{i=1}^{n} \frac{\mu^{2}}{\sigma^{2}}$

(3) Larger is better

$\eta=-10 \log 1 / n \sum_{i=1}^{n} \frac{1}{y_{i}^{2}}$

As the objective of this study is the maximization of cooling tower effectiveness, LB is chosen.Where $\mathrm{n}$ is the number of measurements and $y_{i}$ the parameters being measured through the experiments. The experimental results and corresponding mean and $\mathrm{S} / \mathrm{N}$ ratios are given in Table.4. The average values of cooling tower effectiveness mean and $\mathrm{S} / \mathrm{N}$ ratios for each parameter at different levels are plotted in Fig.3 and Fig.4, respectively. Based on the $\mathrm{S} / \mathrm{N}$ ratio larger is best (LB), WF at $100 \mathrm{~kg} / \mathrm{hr}, \mathrm{AF}$ at $200 \mathrm{~kg} / \mathrm{hr}$ and $\mathrm{WT}$ at $44^{\circ} \mathrm{C}$ are given higher cooling tower effectiveness values. For the three different types of ceramic pacing, maximum cooling tower effectiveness was achieved in the $\mathrm{WF}_{1}-\mathrm{AF}_{2}-\mathrm{WT}_{3}$ conditions and it is observed form the Figures 3 and 4.

Table $3 \mathrm{~L}_{9}$ Taguchi Orthogonal array

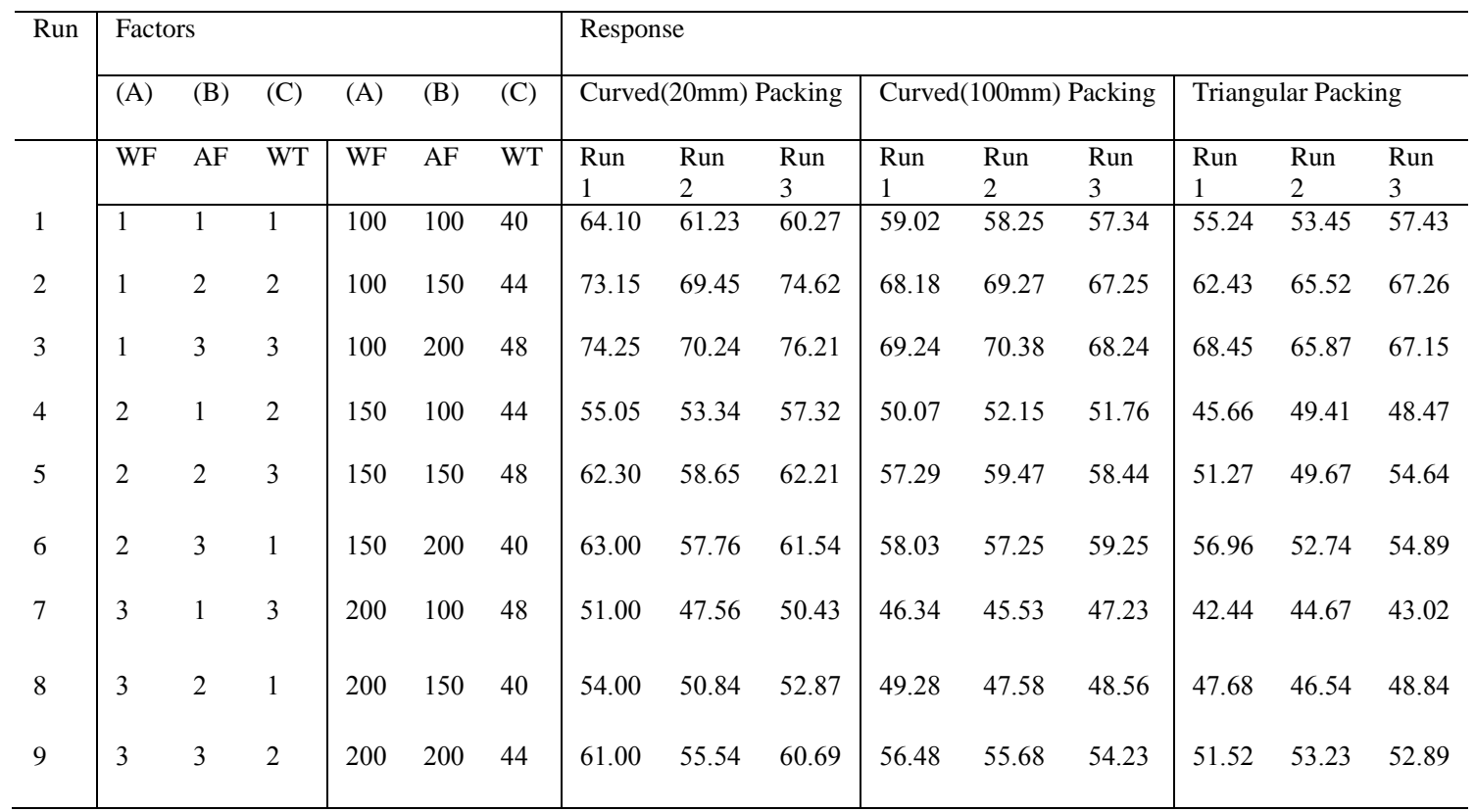


Ramakrishnan and Arumugam / Int. J. of Thermal \& Environmental Engineering, 8 (2014) 45-53

Table 4 Experimental results for effectiveness and S/N Ratio

\begin{tabular}{|c|c|c|c|c|c|c|c|c|c|}
\hline \multirow[t]{2}{*}{ Run } & \multirow[t]{2}{*}{ WF(A) } & \multirow[t]{2}{*}{$\mathrm{AF}(\mathrm{B})$} & \multirow[t]{2}{*}{ WT(C) } & \multicolumn{3}{|c|}{ Mean } & \multicolumn{3}{|c|}{ S/N Ratio } \\
\hline & & & & $\begin{array}{l}\text { Curved } \\
\text { 20mm } \\
\text { Packing }\end{array}$ & $\begin{array}{l}\text { Curved } \\
100 \mathrm{~mm} \\
\text { Packing }\end{array}$ & $\begin{array}{c}\text { Triangular } \\
\text { Packing }\end{array}$ & $\begin{array}{l}\text { Curved } \\
20 \mathrm{~mm} \\
\text { Packing }\end{array}$ & $\begin{array}{l}\text { Curved } \\
100 \mathrm{~mm} \\
\text { Packing }\end{array}$ & $\begin{array}{c}\text { Triangular } \\
\text { Packing }\end{array}$ \\
\hline 1 & 100 & 100 & 40 & 61.70 & 59.10 & 55.00 & 35.80 & 35.43 & 34.80 \\
\hline 2 & 100 & 150 & 44 & 72.05 & 68.15 & 64.67 & 37.14 & 36.67 & 36.20 \\
\hline 3 & 100 & 200 & 48 & 73.42 & 69.25 & 66.67 & 37.30 & 36.81 & 36.47 \\
\hline 4 & 150 & 100 & 44 & 55.02 & 50.05 & 47.33 & 34.80 & 33.99 & 33.49 \\
\hline 5 & 150 & 150 & 48 & 60.77 & 57.30 & 51.33 & 35.66 & 35.16 & 34.19 \\
\hline 6 & 150 & 200 & 40 & 60.33 & 58.10 & 54.00 & 35.59 & 35.28 & 34.64 \\
\hline 7 & 200 & 100 & 48 & 49.33 & 46.40 & 43.00 & 33.85 & 33.33 & 32.66 \\
\hline 8 & 200 & 150 & 40 & 52.00 & 49.35 & 47.00 & 34.31 & 33.87 & 33.44 \\
\hline 9 & 200 & 200 & 44 & 58.67 & 56.50 & 52.00 & 35.34 & 35.04 & 34.32 \\
\hline
\end{tabular}
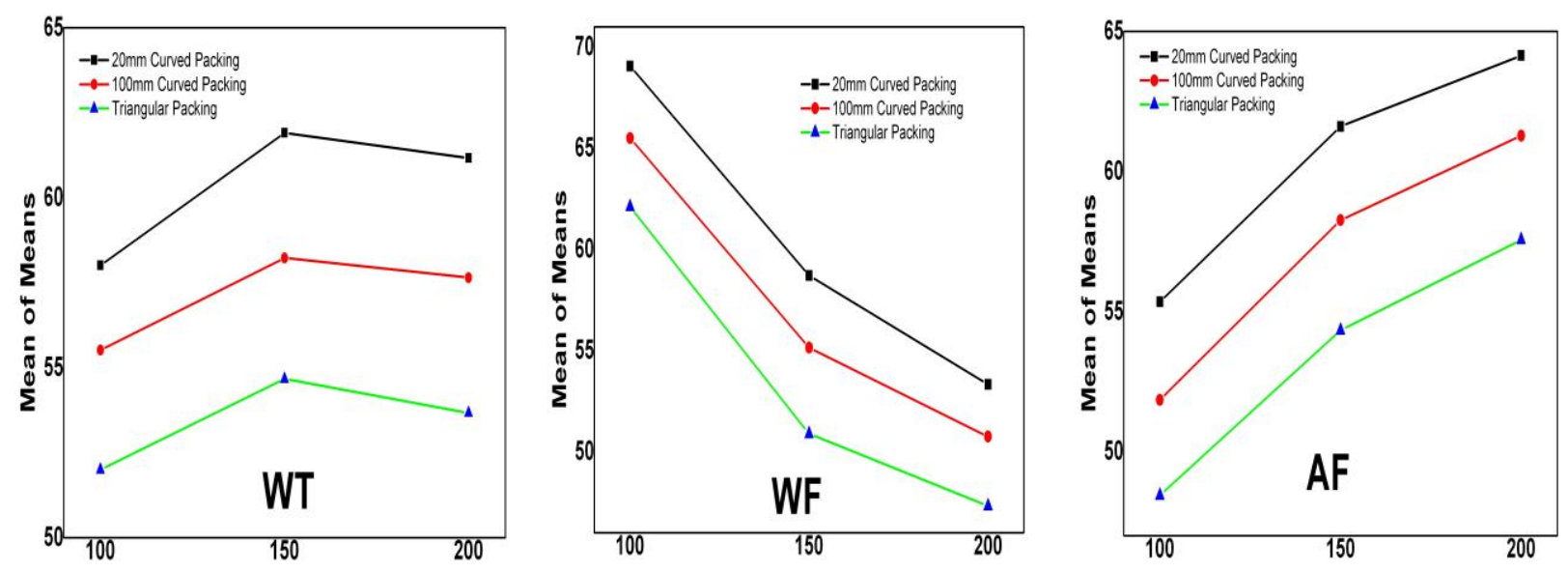

Fig. 3 Average values of cooling tower effectiveness for each parameters at different levels.
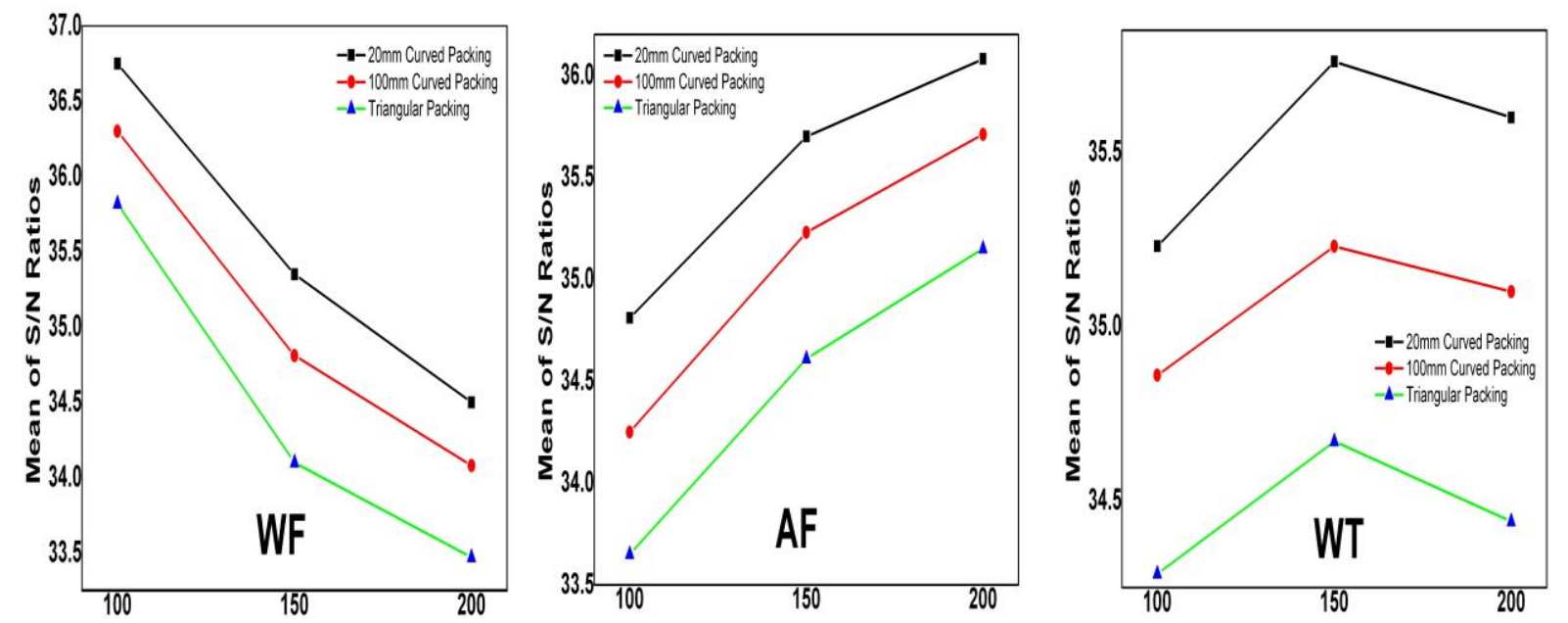

Fig. 4 Average value of $\mathrm{S} / \mathrm{N}$ ratios for each parameter at different levels. 


\section{Analysis of Variance (ANVOA)}

ANVOA is a method most widely used for determining significant parameters on response and measuring their effects. In the cooling tower performance, the major factor of the nonreproducibility is the controls the test facility and the cooling tower operating condition. The ANVOA results for $\mathrm{S} / \mathrm{N}$ ratio and mean are illustrated in Fig $5 \&$ Fig 6 . In ANOVA, the ratio between the variance of the process parameter and the error variance is called as F-test. It determines whether the parameter has significant effect on the quality characteristics. This process is carried out by comparing the F-test value of the parameter with the standard value $\left(\mathrm{F}_{0.05}\right)$ at the $5 \%$ significance level. If F-test value is greater than $\mathrm{F}_{0.05}$, the process parameter is considered significant. It can be seen that all factors are significant. Fig 5\&6 indicates the percentage contribution (significance rate) of each process parameter to the total variation, indicating their degree of influence on the results. According to Fig.5, all the three ceramic packings, inlet Water Flow-WF(72.06\%,67.54\%,70.82\%) has the most dominant effect on total variation and it is followed by inlet Air Flow$\operatorname{AF}(23.56 \%, 29.17 \%, 27.4 \%)$, Inlet Water TemperatureWT $(4.14 \%, 1.88 \%, 1.73 \%)$ has less impact for the cooling tower effectiveness.

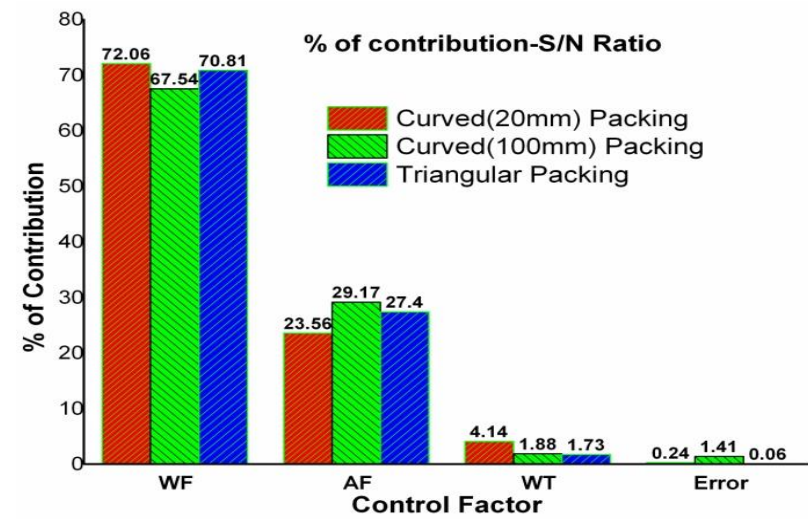

Fig. $5 \%$ of contribution of cooling tower operating parameters by S/N Ratio

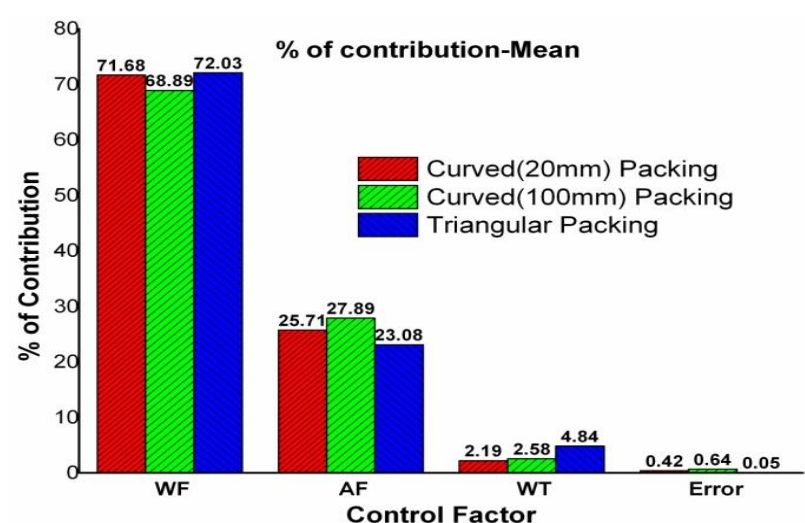

Fig. $6 \%$ of contribution of cooling tower operating parameters by Mean

\section{Regression Analysis}

By mean of regression and correlation analysis, the effect of process parameter on the quality characteristics of cooling tower effectiveness $(\varepsilon)$ was obtained as follows.

\section{0mm Packing}

Mean $=53.4-0.157 \mathrm{WF}+0.0879 \mathrm{AF}+0.395 \mathrm{WT}$

$100 \mathrm{~mm}$

Mean $=53.4-0.148 \mathrm{WF}+0.0943 \mathrm{AF}+0.267 \mathrm{WT}$

Triangular Packing

Mean $=52.8-0.148 \mathrm{WF}+0.09119 \mathrm{AF}+0.208 \mathrm{WT}$

Where $\varepsilon, \mathrm{WF}, \mathrm{AF}$ and WT are cooling tower effectiveness, water flow, air flow and water temperature respectively. $\varepsilon$ is dependent variables and WF,AT and WT are independent variables. Corresponding coded levels given Table 3. It is clear that statistical model can predict the cooling tower effectiveness with sufficient accuracy depending on the obtained correlation coefficients $\left(\mathrm{R}^{2}=96.6 \%\right)$. Predicted results obtained by Eq. 7, 8 \& 9. The cooling tower effectiveness has been predicted using Taguchi and Regression model and the results are shown in Table 5 .

Table 5 Predicated cooling tower effectiveness by Taguchi and Regression model

\begin{tabular}{|c|c|c|c|c|c|c|c|}
\hline \multirow[t]{4}{*}{ Run } & \multirow{2}{*}{\multicolumn{4}{|c|}{$\begin{array}{l}\text { Cooling Tower Effectiveness } \\
\text { Taguchi method }\end{array}$}} & \multirow{2}{*}{\multicolumn{3}{|c|}{$\begin{array}{l}\text { Cooling Tower Effectiveness } \\
\text { Regression Equation }\end{array}$}} \\
\hline & & & & & & & \\
\hline & Curved & & Curved & Triangular & Curved & Curved & Triangular \\
\hline & $20 \mathrm{~mm}$ & & $100 \mathrm{~mm}$ & & $20 \mathrm{~mm}$ & $100 \mathrm{~mm}$ & \\
\hline 1 & & 61.70 & 59.10 & 55.00 & 62.29 & 58.71 & 55.43 \\
\hline 2 & & 72.05 & 68.15 & 64.67 & 68.27 & 64.49 & 60.82 \\
\hline 3 & & 73.42 & 69.25 & 66.68 & 74.24 & 70.28 & 66.20 \\
\hline 4 & & 55.02 & 50.05 & 47.33 & 56.02 & 52.39 & 48.86 \\
\hline 5 & & 60.77 & 57.30 & 51.33 & 62.00 & 58.16 & 54.25 \\
\hline 6 & & 60.33 & 58.10 & 54.00 & 63.23 & 60.74 & 57.14 \\
\hline 7 & & 49.33 & 46.40 & 43.00 & 49.75 & 46.05 & 42.29 \\
\hline 8 & & 52.00 & 49.35 & 47.00 & 50.99 & 48.63 & 45.19 \\
\hline 9 & & 58.67 & 56.50 & 52.00 & 56.96 & 54.41 & 50.57 \\
\hline
\end{tabular}




\section{Confirmation Tests}

The final step is verifying the results based on Taguchi experimental design is the experimental confirmation test. Fig. 6 \& 7 shows the experimental condition including optimal factors settings and indicates the comparative test results for cooling tower effectiveness. From the confirmation test results, average $2.49 \%$ error was obtained between predicted values by Taguchi method, regression model and confirmation test results. It can be concluded that Taguchi method achieves the statistical assessment of maximum cooling tower effectiveness in the counter flow cooling tower with sufficient accuracy. Experimental runs were compared with predicted value and error analyses of the experiments were compared with Standard deviation, S/N ratio and mean. In the confirmation results, $20 \mathrm{~mm}$ ceramic packing having higher cooling tower effectiveness compared with other two types. Because in $20 \mathrm{~mm}$ packing contact of water to air retention time is more But in $100 \mathrm{~mm}$ packing and Triangular packing contact water to air is less due the shape of the packing .Comparison of experimental effect with Taguchi and Regression model are values plotted and it is shown in fig.7.

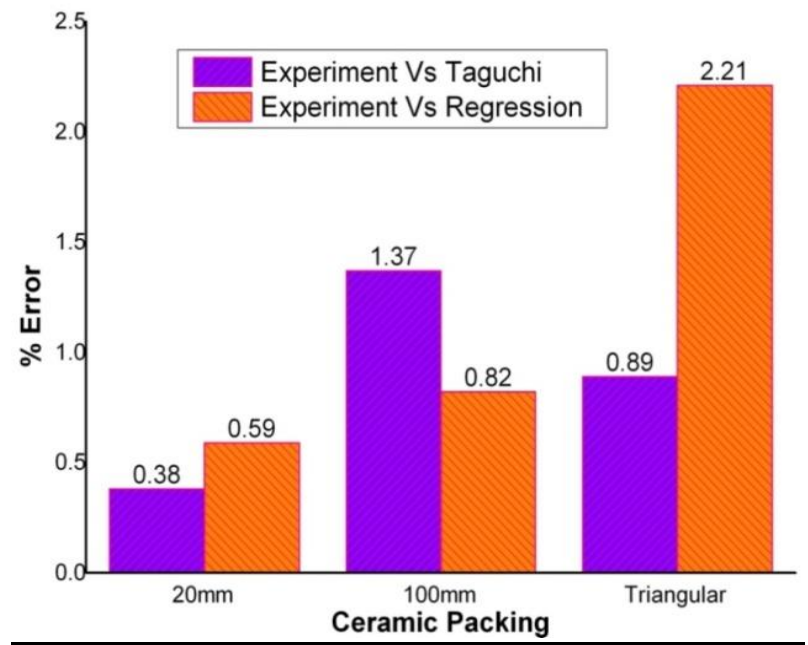

Fig. 6 Comparative of \% Error-Experimental with Taguchi and Regression method

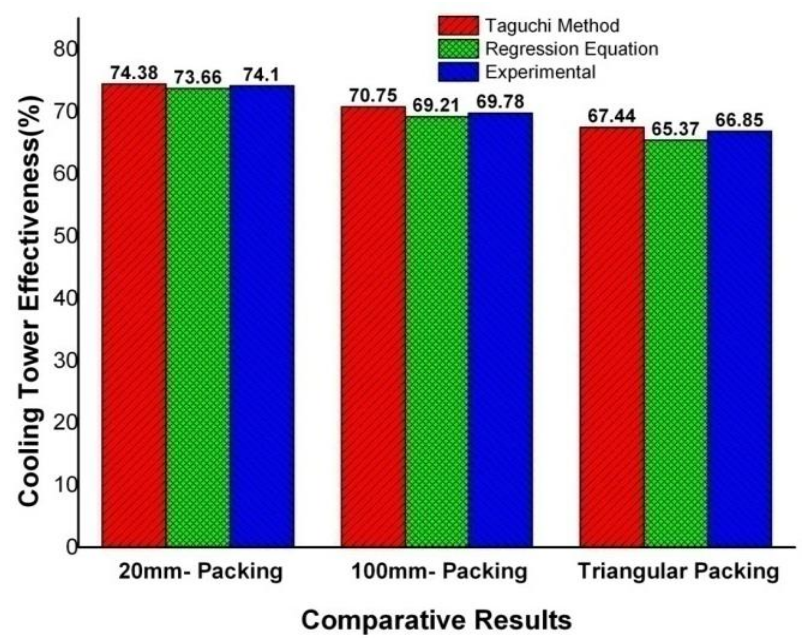

Fig.7 Comparative results of cooling tower effectiveness

\section{Conclusion}

In this article, three different types of packing materials were used in the cooling tower. The effect and optimization of process parameters in counter flow cooling tower on maximum cooling tower effectiveness were investigated through Taguchi methods. From the analysis on the results of cooling tower effectiveness of cooling tower, the following conclusions can be drawn from the study.

- $\quad$ Based on the ANOVA results, all control factors and have significant effect on the quality characteristics statistically.

- Water flow (WF) has the most dominant effect on total variation and it is followed by air flow (AF), and water temperature(WT)

- The effects of control factors and their response were modeled via regression and correlation analysis with $\mathrm{R}^{2}$-value of $96.6 \%$.

- The optimum experiment condition which gives the maximum cooling tower effectiveness was obtained with water flow kept at first level $(100 \mathrm{~kg} / \mathrm{hr})$, air flow kept at third level $(200 \mathrm{~kg} / \mathrm{hr})$ and water temperature kept at third level $\left(44^{\circ} \mathrm{C}\right)$ for all ceramic packing.

- The confirmation experiments at optimum experiment condition was conducted and found that the error between predicted values and confirmation test results is only $2.49 \%$. This result indicates that Taguchi method can be used in the optimization of counter flow cooling tower performance reliably.

- As seen from the optimum results, maximum cooling tower effectiveness was achieved at lower water flow rate, higher air flow rate and medium water temperature.

- $\quad 20 \mathrm{~mm}$ ceramic packing having higher effectiveness was achieved compare with $100 \mathrm{~mm}$ and triangular ceramic packing using optimization techniques.

\section{Nomenclature}

A

$\mathrm{AF}$

DoF

$\mathrm{R}$

$\mathrm{S} / \mathrm{N}$

$\mathrm{T}$

WF

WT

$\mathrm{Y}$

Greek letters

$\mathrm{E}$

$\Sigma$

$\mathrm{M}$

Subscripts

$\mathrm{O}$

W

$\mathrm{Wb}$
Approach

Air flow (kg/hr)

Degree for freedom

Range

Signal to noise ratio

Temperature $\left({ }^{\circ} \mathrm{C}\right)$

Water flow $(\mathrm{kg} / \mathrm{hr})$

Water temperature $\left({ }^{\circ} \mathrm{C}\right)$

Number of parameters

Cooling tower effectiveness $(\%)$

Standard deviation

mean

inlet

outlet

water

wet bulb 


\section{Acknowledgement}

The authors wish to thank the authorities of Annamalai University, Annamalai Nagar, Tamilnadu, India for the facilities provided in the steam laboratory in the department of mechanical engineering to conduct the research work.

\section{References}

[1] Walker, W.H., Lewis, W. K., McAdams, W. H., and Gilliland, E. R., 1923. Principle of chemical Engineering, $3^{\text {rd }}$ ed. McGraw-Hill Inc, New York.

[2] Simpson, W.M., and Sherwood, T. K., 1946. Performance of small mechanical draft cooling towers. American Society of Refrigerating Engineering, 52: 535543, and 574-576.

[3] Kelly, N. W., and Swenson, L.K., 1956. Comparative performance of cooling tower packing arrangements. Chemical Engineering Progress, 52:263-268.

[4] Barile, R.G., Dengler, J .L. and Hertwig, T.A., 1974. Performance and design of a turbulent bed cooling tower. AIChE Symposium Series, 70: 154-162.

[5] Kloppers,J.C., Kroger,D.G.,2003. Loss coefficient correlation for wet cooling tower fills. Applied Thermal Engineering, 23(17): 2201- 2211.[ doi.org/10.1016/ S1359-4311(03)00201-1]

[6] Abdulrahman .Th. M., Sohif Bin Mat, Sulaiman,M.Y., Sopian,K., Abduljalil A. Al-abidi.,2013. Experimental Performance of a Direct Evaporative Cooler Operating in Kuala Lumpur Int. J. of Thermal \& Environmental Engineering, 6(1): 15-20.[ doi: 10.5383/ijtee.06.01.003]

[7] Kloppers,J.C., Kroger,D.G., 2005.A critical investigation into the heat and mass transfer analysis of counter flow wet-cooling towers. International Journal Heat and Mass Transfer,48(3-4):765-777. [doi.org/10.1016/ j.ijheatmasstransfer. 2004.09.004]

[8] Ignatenkov,Y.I., 1979.Study and elaboration of a method for calculating optimum parameters of mass exchange apparatus with vertical grids. Doctorate Thesis, Institute of Leningrad,Russia.

[9] Lemouari,M.,2001.Experimental study of the air/water heat transfer by direct contact in a column packed with vertical grids- application to the water cooling, $M S c$. Thesis, University of Bejaia, Algeria.

[10] Lemouari,M., M. Boumaza,M.,2003. Experimental study of the air/water heat transfer by direct contact in a column packed with vertical grids application to the water cooling. Proceeding 11th International Meeting on Heat Transfer (JITH2003), 2: 457-464.

[11] Lemouari,M., Boumaza,M.,2005. An experimental investigation of thermal characteristics of a mechanical draft wet cooling tower. Proceedings 13th IAHR, Poitiers, France.

[12] Ramkumar.R., Ragupathy.A.,2011. performance analysis of counter flow wet cooling tower. International Journal of Air-Conditioning and Refrigeration, Volume 19(2): 141-148.[ doi: 10.1142/S2010132511000466]
[13] Ramkumar.R., Ragupathy.A., $2014 . \quad$ Thermal Performance Investigation of Mechanical Draft cooling Tower Using Psychrometric Gun Technique. HeatTransfer engineering,35(14-15):1344- 1353.

[ doi:10.1080/01457632.2013.876878]

[14] Ramkumar.R., Ragupathy.A.,2013. Experimental study of cooling tower performance using ceramic tile packing. International Journal of Processing and Application of Ceramics, 7 (1): 21-27. [ doi:10.2298/PAC1301021R]

[15] Amin Mezoued.M., Kaabi.A ., 2013. Effect of Using Packing Material on the Performances of the Double Pass Photovoltaic-Thermal (PVT) Air Heater. Int. J. of Thermal \& Environmental Engineering, 5(1): 61-70. [doi: 10.5383/ijtee.05.01.007]

[16] Naphon,P.,2005.Study on the heat transfer characteristics of an evaporative cooling tower. Int. Comm. Heat Mass Transfer, 32(8): 10661074.[doi.org/10.1016/j.icheatmasstransfer. 2005. 05.016]

[17] Elsarrag,E.,2006. Experimental study and predictions of an inclined draft ceramic tile packing cooling tower. Energ. Convers. Manag, 47(15-16): 2034-2043. [doi.org/ 10.1016/ j.enconman. 2005.12.019]

[18] Gharagheizi,F., Hayati,R., Fatemi, S., 2007. Experimental study on the performance of mechanical cooling tower with two types of film packing, Energ. Convers. Manag, 48(1):277-280. [doi.org/10.1016/j.enconman.2006.04.002]

[19] Benton,D.J., Waldrop,W.R.,1988. Computer Simulation of Transport Phenomena in Evaporative Cooling Towers. J.Eng.Gas Teubine Power,110(2):190196.[doi:10.1115/1.3240102]

[20] Kloppers,J.C.,2003. A critical evaluation and refinement of the performance prediction of wet cooling towers, $P h D$ thesis, Mechanical engineering, University of Stellenbosh, Stellenbosh, South Africa.

[21] Fisenko, S.P., $\quad$ Brin,A.A., Petruchik,A.I.,2004. Evaporative cooling of water in a mechanical draft cooling tower. Int. J. Heat Mass Transfer, 47(1):165-177.[ doi.org/10.1016/S0017-9310(03)00409-5]

[22] Fisenko,S.P., Pitruchik,A.I.,2005. Toward to the control system of mechanical draft cooling tower of film type. Int. J. Heat Mass Transfer, 48(1):31-35.[doi.org/10.1016/ j.ijheatmasstransfer. 2004. 08.002]

[23] Khan,J.R., Qureshi,B.A., Zubair,S.M.,2004. A comprehensive design and performance evaluation study of counter flow wet cooling towers. Int. J. Refrig.,27(8):914-923.[doi.org/10.1016/j.ijrefrig. 2004. 04.012]

[24] Qureshi,B.A., Zubair,S.M.,2006. A complete model of wet cooling towers with fouling in fills. ppl. Therm. Eng, 26(16):1982-1989.

[ doi.org/10.1016/j.applthermaleng.2006.01.010]

[25] Heidarinejad, G., Karami ,M., Delfani, S., 2009. Numerical simulation of counter flow wet cooling towers. Int.J.Refrig,32(5):996-1002.[doi.org/10.1016/ j.ijrefrig. 2008.10.008] 
[26] Taguchi,G., Chowdhury,S., Wu, Y., 2007.Taguchi's Quality Engineering Handbook. John Wiley \& Sons Inc., NewJersey,56-123.[ DOI: 10.1002/ 9780470258354.ch4]

[27] Lin,T.R., 2002. Optimization technique for face milling stainless steel with multiple performance characteristics. Int. J. Adv. Manuf. Technol, 19(5): 330-335.[doi.org/ $10.1007 / \mathrm{s} 001700200021]$

[28] Hasçalik,A., Çaydas,U.,2008. Optimization of turning parameters for surface roughness, and tool life based on the Taguchi method. Int. J. Adv. Manuf. Techno, 38(9-10): 896-903.[doi.org/ 10.1007/s00170-007-1147-0]

[29] Chan, C.C., Hsu,W., Chang,C., Hsu,C., 2010. Preparation and characterization of gasochromic Pt/WO3 hydrogen sensor by using the Taguchi design method. SensActB, 145(2):691-697.[doi.org/10.1016/j.snb. 2010. $\underline{01.021]}$

[30] Tsai ,T.N.,2011. Improving the fine-pitch stencil printing capability using the Taguchi method and Taguchi fuzzybased model. Robot Comput Integr Manuf, 27(4):808817. [doi.org/10.1016/j.rcim.2011.01.002]

[31] Mallick,Z.,2010. Optimization of the operating parameters of a grass trimming machine. Appl Ergon,41(2):260-265.

[ doi.org/10.1016/j.apergo.2009.07.010]

[32] Kishore, R.A., Tiwari, R., Singh, I., 2009. Investigation of drilling in $[(0 / 90) / 0] \mathrm{S}$ glass fibre reinforced plastics using Taguchi method. Adv Prod Eng Manage 4(1-2):37-46.

[33] Kansal, H.K., Singh, S., Kumar, P., 2005. Parametric optimization of powder mixed electrical discharge machining by response surface methodology. $J$ Mater Process Technol, 169(3): 427-436. [dx.doi. org/10.1016/ j.jmatprotec.2005.03.028

[34] Jun Li., Yongwei Zhu., Dunwen Zuo., Yong Zhu., Chuangtian Chen., 2009. Optimization of polishing parameters with Taguchi Method for LBO crystal in CMP. J Mater Sci Technol, 25(5):703-707. [http://www.jmst. org/EN/ Y2009/V25/I05/703]

[35] Tsai, C.S.,2002. Evaluation and optimisation of integrated manufacturing system operations using Taguchi's experiment design in computer simulation. Comput Ind Eng,43(3):591-604. [doi.org/10.1016/ S03608352(02)00127-4]

[36] Tsai, T.N., 2011. Improving the fine-pitch stencil printing capability using the Taguchi method and Taguchi fuzzybased model. Robot Comput Integr Manuf, 27(4):808 817.[ doi.org/10.1016/j.rcim. 2011.01.002]

[37] Suhail, A.H., Ismail, N., Wong, S.V., and Abdul Jalil,N.A.,2010. Optimization of cutting parameters based on surface roughness and assistance of workpiece surface temperature in turning process. Am J Eng Appl Sci,3(1):102-108.[doi : 10.3844/ ajeassp. 2010.102.108]

[38] Mehat, N.M., Kamaruddin. S., 2011. Optimization of mechanical properties of recycled plastic products via optimal processing parameters using the Taguchi method.JMaterProcessTech,211(12):1989 1994.[doi.org/10.1016/i.jmatprotec. 2011. 06.014]. 